\title{
Sunday, Bloody Sunday
}

\section{A Field Marshall}

On Easter Sunday (April 11,1993) at the Southern Ohio Correctional Facility (SOFC) located in Lucasville, Ohio, the years of oppression exploded into a full-blown riot. For all familiar with the treatment and conditions there, it was known to be long overdue. Brutality, racism, murder, and inhumane treatment have been documented with the state and federal courts as well as with Amnesty International and other human rights organizations - yet the prisoncrats just kept tightening the screws.

Years of whitewashing by the state legislative watchdog committee (Correctional Institution Inspection Committee, CIIC) didn't help. The CIIC in 1990 called for a full-scale investigation into conditions at Lucasville that they turned into a political fiasco by creating an 800 member Aryan Brotherhood (AB) and focusing on that aspect, saying the $A B$ controlled gambling, drugs, and prostitution inside the prison. No mention was made of the other factions, and the fallacy about the $A B$ just caused younger prisoners to want to start one or join. Governor Celeste called for a full-scale investigation by the State Highway Patrol after the FBI, SHP and CIIC had just investigated allegations of two black prisoners being killed by white guards for touching a white nurse. All the SHP did was twist and turn their investigation to cover for the guards' and prisoncrats' illegal activities. SHP also called for more security; the hiring of additional guards and putting the prison on senilockdown. This created the increase in tension and oppression that led to the events of the Bloody Easter Sunday riot. The failure of the courts and legislature to provide relief from the oppressive conditions, coupled with the constant harassment of prisoners who tried to use legal avenues to address the everyday constitutional violations left only one option - revolution. Judges, politicians, and even prisoncrats pay lip service to the public about how prisoners should and are encouraged to use the courts and grievance system to air complaints and violations. In reality, they bog down prisoner cases for years, dismissing $90 \%$ of them without a trial, then retaliate with long-term isolation in control unitscell and body searches for harassment purposes and the thousands of other ways they harass us.

The years of frustration came to a head when forced/mandatory TB testing was done after the state had put active TB carriers in areas of the prisons where it could spread-refusing to isolate them properly. When gorilla tactics were used by prisoncrats to enforce this mandatory testing, prisoners rebelled. What started as a spontaneous event turned into a takeover of all of L Side, the taking of eight guards hostage, and the killing of nine prisoners and one guard before the takeover was 
Journal of Prisoners on Prisons, Vol. 5, No. 1, 1993.

over. The prisoners were liberated and some of those who refused to participate were beaten and some were killed. The takeover/riot began at approximately 2:45 PM on Easter Sunday and didn't end until the last hostages were released unharmed and the prisoners surrendered on National TV eleven days later. The negotiated surrender was made possible when Niki Schwartz, a civil rights attorney from Cleveland, Ohio, was called in to assist and advise the prisoners involved. It is still rumoured, and unofficially confirmed by some prisoners involved, that there is a much larger body count of prisoners killed, but the state is covering it up. Right now the Ohio Department of Justice is calling the shots at the prison.

Approximately 330 to 340 prisoners, who were on the recreation yard when the riot began, remained there until approximately 3:30 AM when over 200 guards, dressed in riot gear, entered the yard. They herded the prisoners into the gym, stripped them naked, and threw all their belongings into a community pile (this property hasn't been recovered to this day). Handcuffed behind their backs, prisoners then marched naked down K Corridor while female and male guards madecomments about their nudity and manhood. They were then locked up, five to ten prisoners in a cell. It took more than four hours before the handcuffs were removed. Prisoners remained in these conditions for four days: five to ten in a cell, no medical attention, no anything except for a couple of cold-cut sandwiches a day until they were moved to one-man cells. One prisoner, Dennis Weaver, who had a history of litigations but who was a non-participant, was killed while on $\mathrm{K}$ side. The way he died has not been confirmed to this writer.

During the riot and negotiations, the Department of Corrections spokesperson repeatedly treated the incident as a joke. This was the same tactic used when the four Brothers took control of JL supermax back in 1985, and it is a common tactic used by the state. It backfired this time, leading to the execution of a guard, Robert Villandinghams.

The prisoners hung sheets out the windows telling the media that the state wasn't playing fair. The state's response was to move the media away from L Block so they could neither see nor hear the prisoners. After Villandinghams' body was dumped from a window, the state started taking the prisoners seriously. During all this, rumours abounded: it was reported from unnamed sources that there were seventeen to fifty bodies stacked in the L Side gym and to this day there are confirmed reports of more prisoners killed at the beginning of the riot than the DRC is reporting. I' $m$ told that the Justice Department is calling the shots now and a cover-up (at least to the media) is being done vis-à-vis body counts.

Demands were issued to the DRC at the start; the different factions inside the prison worked together after the initial takeover. While the media reported there was dissension amongst prisoners, it was, in fact, at a minimum. One of the problems is forced integration. The reason the state is able to maintain the fallacy about an Aryan Brotherhood is 
because those prisoners who don't want to be forced into integrated celling have to say that they' re racists in order to obtain a 'Green Card.' Such a card is a tag in a prisoner's file saying it is against his religion or philosophy to cell with another race. Those who have done time know that a lot of Black/White cells are homosexuals and their Man, and this has been a stigma against integrated cells (see White v. Morris consent decree). It is even recognized by leading jurists that integration by court order is no longer effective. Integration in prison should be by choice due to the volatile environment.

Demands that the state agreed to consider were:

1 Follow all administrative rules and regulations.

2 Administrative discipline and criminal proceedings will be fairly and impartially administered without bias against any specific individuals or groups.

3 All injured parties will receive prompt medical care and follow-up.

4 The surrender will be witnessed by religious leaders and news media.

5 The unit management system will be reviewed with attempts to improve in areas requiring change.

6 SOCF will contact the federal court to review the White v. Morris consent decree that requires integrated celling.

7 All close-security inmates have already been transferred from K side, and $\mathrm{L}$ side close-security inmates will be immediately evaluated for transfer.

8 Procedures will be implemented to thoroughly review prisoners' files pertaining to early release matters and changes will be made where warranted.

9600 inmates transferred to relieve overcrowding.

10 Current policies regarding inappropriate supervision will be rigidly enforced.

11 Medical staffing levels will be reviewed to ensure compliance with ACA standards for medical care.

12 Attempts will be made to expedite and improve work and program opportunities.

13 The DRC will work to evaluate and improve work and program opportunities.

14 There will be no retaliatory actions taken toward any prisoner or group of prisoners or their property.

15 A complete review of all correctional facility mail and visit policies will be undertaken.

16 Transfers from the correctional facility are coordinated through the Bureau of Classification. Efforts will be increased to ensure prompt transfers of those prisoners who meet eligibility requirements.

17 Efforts will be undertaken to upgrade the channels of communication between employees and prisoners involving quality of life issues.

18 The complete commissary pricing system will be reviewed.

19 The DRC will consult the Department of Health regarding any further TB testing. 
20 The FBI will monitor processing and ensure that civil rights will be upheld.

21 The DRC will consider case by case the interstate transfer of any prisoner if the DRC feels that there is a reasonable basis to believe that they would be unable to provide a secure environment for that prisoner. Any prisoner denied transfer will be reviewed by the Federal Bureau of Prisons.

On Monday April 12, 1993, the bodies of six prisoners were placed on the yard for the DRC to pick up. They had been beaten and hanged. All were older prisoners, some who refused to participate in the riot, some who were snitches. On Tuesday, prisoners had dismantled windows and went from $\mathrm{L}$ Side to $\mathrm{K}$ side and got prisoners in K-8 to destroy their cells. Back in the AC Blocks, prisoners tore out their cell lights and wiring, beat on their cell doors, and started fires with all state-issue property. This was not shown on TV. On Wednesday the 13th, a helicopter manned by the Ohio National Guard and Northern Assistant Regional Director Joe McNeil had engine failure and crashed outside the prison, injuring those inside, while another officer broke his leg trying to rescue those inside the helicopter. Governor Voinavitch ordered 500 National Guard to surround the prison, replacing the Ohio State Highway Patrol. Water, food, and prescription medication were delivered to the prisoners. All water, electricity, and food had been cut off since the beginning of the takeover. In exchange for the release of a hostage, the prisoners were given airtime on TV. A prisoner identified as 'Inmate George' (later a private investigator called the media telling them that 'Inmate George' was George Skaizes, a former client who she believed to be innocent of the murder for which he was imprisoned) told the public that all prisoners of all races joined together in unity during the takeover to show the public the oppressive conditions they were living under and that they were all willing to die if their demands were not met. They called for the firing of Warden 'King Arthur' Tate. Guard, Darrold R. Clark, was released as a result of the broadcast. George also a pologized to Villandinghams' family for his death, saying it was sad but necessary. He also told the family of another hostage, Bobby Ratcliffe, that he was all right and would be home soon. The hostages were well treated and guarded by the Muslims and White Brothers.

On Friday the 16th, prisoner, Abdul Samad Mulin, and guard, James Demons, were permitted out on the yard where an impromptu press table was erected and two state negotiators sat allowing media coverage of the event. Abdul Samad called upon the Muslims of the world to monitor the situation and to retaliate if any of the Brothers were killed by the state. He then went on to voice the complaints of the Muslims regarding the SOCF refusal to allow their prayergarb and other issues pertaining to the customs of Islam. It was obvious that they were given a limited time to voice these issues. He also stated that the mandatory TB testing violated their religious tenets and had sparked the incident, and told how the Security Point Classification system and transfers 
were unfair. Guard, James Demons, was garbed in a Muslim robe and stated that he felt the incident could have been prevented and that shutting the water and power off jeopardized the hostages lives. He also said that the prisoners killed were not killed by the Muslims and were killed for being snitches. He was then led off the yard and none of his fellow pigs clapped or cheered for his release. He would later tell the media that he acted like he embraced Islam merely to save his own life and that he resented the way the situation was handled as Villandinghams' life could have been saved if the state would have taken matters seriously.

When Niki Schwartz was brought in, things got going more smoothly. On April 21, 1993, eleven days after the riot started, the negotiated settlement of the 21 points (listed above) were accepted and the surrender of the prisoners on national television began. Prisoners were shipped to MANCI, Trumball, Lebanon, Lorain, and Chilicothe.

The fact remains that Ohio's prisons are operating at $200 \%$ overcapacity and the conditions are so bad that the same situation is liable to happen at any of these prisons. The public attitude that supports stiff sentences and more prisons does not deal with the root problems of crime. As long as there is racism, unemployment, sexism, poverty, drug use, and inadequate community resources for children and young adults, the crime rate will continue to escalate. President Clinton's plans for the criminal injustice system involve more funding to hire more police which will lead to more arrests and imprisonments, all of which translates into more overcrowding. One issue that the Brothers at Lucasville didn't touch on, or the state wouldn't let out, is the fact that the Adult Parole Authority isn't paroling enough prisoners who merit parole and the Governor refuses to exercise his authority of emergency releases of prisoners in overcrowding situations. The parole board members have ultimate power over prisoners and often exercise it arbitrarily and capriciously, though there is an Ohio Criminal Sentencing Commission ready to issue a report to require mandatory sentences, but also more community alternatives to prison. The sentencing structure in Ohio is ridiculous. Some prisoners are serving sentences in excess of 100 years for offenses that in other states would get two or three years flat. It has been proven that the longer the incarceration the more detrimental the effect. But prisons are industries nowadays, employing people in rural areas and creating an enormous job pool, so penalties get increased to maintain the business.

What is the answer? Obviously, rioting isn't the best way to bring about change due to the violence that goes with it. However, when men are treated like animals with no alternative means of getting justice, rioting is the only avenue left to focus the public eye on what is happening in our prisons. Now, hopefully, committees will be formed to bring about positive change. It's up to those in the progressive community to make this happen. I would urge those attorneys, legislators, and civil rights groups to join together and try to organize 
committees to make the state address all these prisoners' issues so there's not another blood bath. Those involved need your support more than ever to fend off the multitude of forthcoming criminal charges as well as retaliation by the state. Remember we are in here for you and you are out there for us. Solidarity 